\title{
Noëmie Lucas
}

\section{Landowners in Lower Iraq during the $8^{\text {th }}$ Century: Types and Interplays}

\begin{abstract}
This paper aims to identify types of landowners in Lower Iraq, where land was a social, political and economic issue, especially during the $8^{\text {th }}$ century. The focus on landholders determines the characterisation of the imperial as well as regional Lower Iraqi elite. It takes into consideration Jewish and Christian landowners (for example, ecclesiastical landed elites in the Nestorian community), Persian landowners (for example, the dahāqin who settled in the region before the Islamic conquest) and the landed Islamic elites (who are related to the conquering group). With this typology, I shed light not only on the diversity of landed elites in Lower Iraq but also on the subgroup of Islamic landowners. Defining landowner groups is a prerequisite to the study of the interplay between local and imperial elites over the course of the $8^{\text {th }}$ century. This period is regarded as that of the rise of Islamic elites. Researchers agree these elites were no longer specifically bound to military functions, a development with consequences for other landed groups. Subsequent interplays took place in the context of inter- and intra-group relationships. This paper seeks to offer a typology of these interactions in order to understand the relationships and power ratios at stake.
\end{abstract}

Keywords: Iraq; landholding; social conditions; Umayyads; 'Abbāsids

\section{Introduction}

In Akhbār al-quḍāt, ${ }^{1}$ Wakī' reports that between $173 \mathrm{H} / 789-90 \mathrm{CE}$ and $181 \mathrm{H} /$ 797-98 CE in al-Bașra, then-judge 'Umar b. Habīb had to adjudicate a conflict between Yahyā b. Khālid al-Barmakī and some inhabitants of al-Bașra (probably landowners) regarding the fraudulent appropriation of estates. ${ }^{2}$ Yahyā was

This article is part of an ongoing doctoral research devoted to the power of land in Lower Iraq during the 8th century. This research is conducted under the supervision of Prof. Anne-Marie Eddé at Panthéon Sorbonne University (Paris).

1 Judicature of 'Umar b. Ḥabīb in al-Bașra: 173 H/789-90 CE to 181 H/797-98 CE.

2 Wakī', Akhbār al-quḍāt, II, 143-144; Tillier 2009, 295; Sourdel 1960, I, 172.

Ә OpenAccess. () 2020 Noëmie Lucas, published by De Gruyter. (cc) BY-NC-ND This work is licensed under the Creative Commons Attribution-NonCommercial-NoDerivatives 4.0 License. 
blamed, through his representative and intendant al-Qașabī, for appropriating lands which already had owners. Eventually he failed to establish his claim. ${ }^{3}$

This story offers a point of access to landholding issues at the end of the $8^{\text {th }}$ century. It also provides information about landowners in the region of Lower Iraq. Yahyyā b. Khālid al-Barmakì was part of the imperial elite during the early 'Abbāsid period. He and his relatives were major landlords in al-Bașra's region ${ }^{4}$ and later also in Baghdad or al-Raqqa. ${ }^{5}$ They were not specifically tied to the Lower Iraqi region, therefore they were imperial rather than regional landowners. The identity of the Bașran landlords suffering from Yahyyā's actions is not specified. Their religious, social or economic backgrounds are unknown but one can assume that they were part of the Bașran (local?) elite. Therefore, the conflict in which Yahyā was involved opposed imperial and regional landowners and highlighted the competition for land between imperial and regional elites. This story also shows that the purchase of Lower Iraqi lands may have occurred at the imperial elite level as Yahyā bought $\left(a b t \bar{a}^{\prime} a\right)$ lands from the caliph Hārūn al-Rashīd. ${ }^{6}$ However, these lands may also have been personal possessions of Hārūn al-Rashīd or have been part of the bayt al-māl.

This conflict exposes that landholding was a topic of discussion in Lower Iraqi society and an economic and political issue during the $8^{\text {th }}$ century. It also proves that studying landholding in Lower Iraq is relevant to understanding the formation of the Islamic imperial elite as well as the evolution of the regional elites, especially during the $8^{\text {th }}$ century.

The sources preserved from this period are sparse for the historian of early Lower Iraqi society. The available materials produced at the end of the $8^{\text {th }}$ century are mainly legal works: for example, the Kitāb al-Kharāj written by Abū Yūsuf ${ }^{7}$ and then Yahyā b. Ādam, ${ }^{8}$ or the Kitāb al-Amwāl of Ibn Sallām. ${ }^{9}$ These booksdevoted to Islamic finance, taxation systems and economic issues-contributed to legal codification. They contain many significant questions related to lands and land taxation or landownership. This importance shows the land-based concerns of the 'Abbāsid state (in formation at that time) and its desire for a systematized tax-system. The region of Lower Iraq is well depicted in these legal works; al-Sawād is the subject of specific chapters. East Syrian sources, like the Judg-

3 Wakī', Akhbār al-quḍāt, II, 144; the qāḍi decided in favor of the Bașran population.

4 Sourdel 1960, I, 154; many mentions in al-Jahshyārī, Kitāb al-Wuzarā', 189/229, 216-217/266.

5 Al-Jahshiyārī, Kitāb al-Wuzarā', 235/293.

6 Wakī‘, Akhbār al-quẹāt, II, 143-144.

7 Abū Yūsuf, Kitāb al-Kharāj.

8 Yaḥyā b. Ādam, Kitāb al-Kharāj.

9 Ibn Sallām, Kitāb al-Amwāl. 
ments of Henanisho' and more generally canonical judgments, along with Jewish documentation like Geonic responsa, discuss land matters as they relate to inheritance or tax. These materials strengthen the relevance of studying landowners of this time and confirm that landholding was a discussed topic in society and an economic and political issue.

The formation of an urban Muslim aristocracy or a Muslim bourgeoisie can be situated with or shortly before the composition of these sources. ${ }^{10}$ The $8^{\text {th }}$ century in Lower Iraq is often seen as the period of the formation of an Islamic elite who were no longer specifically bound to military functions. Obviously this change had much to do with lands and landholding. This rise is twofold, inasmuch as it accompanied the economic and cultural growth of the region. The urban triangle of al-Bașra, al-Kūfa and Wāsiț, with their respective sawād and swamps (al-bațäih), played a key role in this formation of an elite as well.

The beginning of the period is marked by the suppression of Ibn al-Ash'ath in 81-82 H/700-701 CE. Following this upheaval, al-Ḥajjāj founded Wāsiṭ, a new administrative and military capital, and the two cities of al-Bașra and alKüfa were demilitarized. These circumstances did not prevent this area from flourishing. This thriving situation can be observed until the $9^{\text {th }}$ century, when the Zanj revolt broke out in $255 \mathrm{H} / 869 \mathrm{CE}$. Its consequences were far-reaching. However, the arrival of al-Ma'mūn in Baghdad in 204 H/819 CE is chosen here as an end point. This is owing to the emigration of some members of the elite from Lower Iraq to the capital and more broadly to the intensified centralization of that time. The dynastic rupture of $132 \mathrm{H} / 750 \mathrm{CE}$ has to be taken into account, and consequent changes or continuity in landholding and landowners have to be kept in mind.

Many aspects of the Lower Iraqi region were singular within the Islamic Empire. The main region of settlement for the conquerors was Lower Iraq, due to the foundation of the two amșār al-Bașra and al-Kūfa. It was an area previously inhabited by important Jewish and East Syrian populations, mostly Aramaic but also Arabic speakers, and to a lesser extent by Sasanian Zoroastrian groups. These populations, who remained after the conquest owners of their lands, were in the majority during most of if not the entire period we are concerned with.

Lower Iraq is an alluvial land on the Euphrates and Tigris. Because of the climate-hot and arid-even fertile agricultural areas had to be irrigated, entailing the construction of irrigation canals. In $8 \mathrm{H} / 629 \mathrm{CE}$, just before the Islamic conquest, dams breaking caused the Tigris to change its course and inundate

10 Crone 1980, 51; Decobert 1991, 81. 
large parts of cultivated land. These became marshes. ${ }^{11}$ In contrast, the area close to the former course of the Tigris became a desert. This new swamp was frequently called al-baținha. Heavy investment in the system of irrigation and its upkeep were necessary, as well as the revival of dead lands and the clearance of swamps in order to make land farmable. Despite that, Lower Iraq can be considered a cultivated area during this entire period and more specifically after the foundation of Baghdad because it participated in the food supply of the capital.

A central region of the Islamic Empire during the period we are concerned with, Lower Iraq witnessed a number of changes in imperial dynamics. Whereas Lower Iraq was previously a province of the Umayyad Empire, whose capital was located in Damascus in Syria, it became the heart of the 'Abbāsid Empire with the settlement of the dynasty in this area and with the foundation of Baghdad. This movement toward Iraq had consequences. Lower Iraq was no longer peripheral to the capital; from now on it was situated in the area of influence of Baghdad in Upper Iraq. Nevertheless the region remained distinct. For the purpose of this study, these changes and the relationship between Lower Iraq and Baghdad have to be considered in order to understand the implications for landholding and landowners in the area.

This paper seeks to identify landowners in Lower Iraq during the $8^{\text {th }}$ century. In the abstract, trying to answer the question 'who were the landowners in this area during one century?' forces us to pay particular attention to the evolution and/or reproduction of landowners. One century after the conquest, it is necessary to measure the changes or lack thereof brought by the end of Sasanian and the emergence of Islamic rule. The building and politics of the Umayyad state have to be taken into account. As far as the 'Abbāsid takeover, it obviously obliges us to consider the question of reproduction or modification. But in the game of local vs. imperial dynamics, it seems more relevant to question landholding in terms of regional and/or imperial landowners. This serves as a way to go beyond the use of religious or ethnic classifications-though they can prove relevant. Moreover, one of the questions to arise from these categories is: were Lower Iraqi landowners regional elites? In other words, were they tied to the region? Did their properties make them part of Lower Iraqi society or not?

This consideration can be related to Claude Cahen's theory regarding the rural economic history of the medieval Middle East. ${ }^{12}$ According to him, during the $10^{\text {th }}$ century a decline in small landholding and the assertion of power by big landowners can be observed. The deterioration of the peasant condition could be

11 Ibn Rusta, Kitāb al-A 'āq an-nafīsa, 95; al-Balādhurī, Futūḥ, 292-293.

12 Cahen 1953. 
seen as the result of a long process in which the $i q t \bar{a}^{\prime}$ and its wider enforcement figured. ${ }^{13}$ Under that theory, the Būyid period would show a surge in property being grabbed from small landowners. ${ }^{14}$

In my opinion, this appealing theory has to be put to the test-not to deny or confirm it but in order to gain a better understanding of it. A study on landowners in Lower Iraq during the $8^{\text {th }}$ century, about two centuries before the Būyid period, may be useful to gain a better view of the process of decline of small landholding, and to underline chronological ruptures and differences.

As is suggested by the title of this paper, I am going to focus mainly on landowners (that is, people) and not processes. This work is not about landholding as such. ${ }^{15}$ I prefer to take a prosopographical approach-even one that is not systematic-and try to provide a classification. This prosopographical perspective pertains to the characterization of Lower Iraqi elites, whether regional or imperial, but also seeks to appraise the long process described by Cahen. The 'peoplebased' point of view forms a useful basis to understanding inter-group and intragroup relationships.

This work will offer a typology of Lower Iraqi landowners, using regional and imperial elites as initial classifications. Obviously, the distinction between the two categories is not rigid. The Arab conquerors who arrived in Iraq were participating in the imperial project of the Islamic conquests. They were at first imperial elites, but since they settled in al-Bașra and/or al-Kūfa with their families and remained attached to the region, they can be considered by the $8^{\text {th }}$ century as regional elites. Such settlement in the region of Lower Iraq can be seen as an indication of regional ties. On the other hand, imperial landowners may also refer to trans-regional elites, that is to say, those who participated in the working of the early Islamic Empire without being bonded to a specific region. The Umayyad family can be regarded as part of this group of imperial landowners.

I am aware of the blurring dimensions of these categories and of the difficulty in assigning one person to one box. The overlap between types will be to a certain extent discussed and questiond in the course of this study. However, it is useful to first identify these types separately in order to later examine the interplays existing between each group. This interplay will be the focus of the second part of this paper. In short, the pattern of Lower Iraqi landowners will be

13 Cahen 1953.

14 Cahen 1953, 34.

15 I will not return to the debate on private landed property in the Islamic world; I predicate that it existed though I am aware it is and has to be a subject of discussion. For landholding in early Islamic Iraq and debates about private landed properties, see Morony 1981 and Kennedy 2014. 
drawn out, and then the way imperial and local forces met, intertwined or faced will be taken into consideration.

\section{Regional Landowners}

Jewish and Christian landowners who inhabited Lower Iraq before the Islamic conquest and continued to own their lands afterwards can be simply referred to as non-Muslim elites. The situation of Zoroastrian landowners is more difficult to comprehend. Islamic legal sources composed at the end of the $8^{\text {th }}$ century frequently debate the question of land status in al-Sawād with regard to the way the region was conquered.

It is worth considering the context of composition for these sources and the so-called historical narratives formulated in the associated treaties. ${ }^{16}$ Whatever the narrative, the facts show that non-Muslim landowners continued to own their lands after the conquest. This is corroborated by the study of șulhan- 'anwatan traditions. ${ }^{17}$ East Syrian sources regarding this matter (for example, the Judgments of Henanisho') and Jewish sources ${ }^{18}$ reinforce that there were still nonMuslim landowners in Lower Iraq at the end of the $8^{\text {th }}$ century and beyond. In this study, avoiding religious terminology is difficult given the available material on these landowners. As the sources are from legal-religious backgrounds, they promote the classification of regional landowners according to religious affilia-

\footnotetext{
16 Knowing that the book of Abu Yūsuf was written at the request of the caliph confirms the state desire for codification and systematization. The emergence of taxation literature at a time when tax systems were systematized and re-organized forces us to draw a link between composition and codification. The book of Yahyā b. Ādam was written at the same period or shortly after the one of Abū Yūsuf. It might have been composed for his students (we do not have detailed indications of the reasons behind the composition) but it was in line with Abu Yūsuf's work. Ibn Sallām's Kitāb al-Amwāl was not a commissioned work but its composition can be related to land and tax cases Ibn Sallām dealt with at Ṭarsūs when he was qāḍì, and thus considered indicative of his will to resolve various issues concerning Islamic finance. More generally, the composition of these treaties was concurrent with a general period of formation regarding administration and legal codification.

17 See Noth 1974 (2008). In this article, A. Noth offers a study of these traditions, especially those of the Sawād, and he corroborates that the ownership of the land of Sawād did not pass to the Muslims after the conquest.

18 See Sachau 1908, II, which contains the Judgments of Henanisho' and the Regulations for Ecclesiastical Judgments and Inheritance of Timothy I. As for responsa, according to Brody $(1998,186)$ approximately 5,000 - 10,000 responsa survive but only a small portion has been published in the various collections of Geonic responsa. Examples of collections include Lewin, Oșar ha-Geonim, and Neubauer, Mediaeval Jewish Chronicles and Chronological Notes.
} 
tion. However, a distinction has to be made between individual lay landowners and ecclesiastical or religious properties that implied a non-individual ownership.

\section{Landowners within the Jewish Population}

Prosopographical study of Jewish landowners in Lower Iraq is very sparse, but some evidence suggests that a group were regional landowners during the $8^{\text {th }}$ century. At the end of the Sasanian period, the large Jewish population of Lower Iraq was mainly settled to the north in the sawād of al-Kūfa, ${ }^{19}$ although we can also find some in the region of Maysān. ${ }^{20}$ A large number, especially in the countryside, were farmers, either as owners of their lands or tenants. Larger wealthy landowners, however, have to be taken into account. Newman ${ }^{21}$ has provided a lot of information about them. ${ }^{22}$

It is worth mentioning that during the last centuries of Sasanian rule, wealthy Jewish landowners took advantage of the difficulties faced by small Jewish peasants and increased their own estates by buying up the debts of small landlords. ${ }^{23}$ It means that at the time of the conquest some Jewish landowners owned large estates and even villages in Lower Iraq. But it is also necessary to consider the continued presence of smaller landlords. At the other chronological boundary, the end of the $8^{\text {th }}$ century, a Geonic decree (taqqanah) promulgated by the academy of Sura and the Exilarch is indicative of the fact that Jewish landowners still owned estates in Lower Iraq while at the same time pointing out some changes. ${ }^{24}$ This decree, dated 169-170 H/786-787 CE, added some changes to Talmudic laws regarding the collection of debts from the heirs of a deceased debtor. Previously a creditor could only claim the landed property belonging to the deceased parent of orphans. Following the new ordinance, debts could be collected from movable property as well. This taqqanah is often quoted to indicate the diminishing numbers of landholding Jews at the end of the $8^{\text {th }}$ century. However, some responsa from the $9^{\text {th }}$ and $10^{\text {th }}$ centuries show that Jewish

19 Morony 1984a, 309.

20 Morony 1984a, 309.

21 Newman 1932.

22 Newman 1932, 33-46.

23 Morony 1984a, 310.

24 Lewin 1928-1945, Ketubbot, Responsa, no. 535. About this decree: Brody 1998, 63; Morony 1984a, 312; Newman 1932, 35-36; Ackerman-Lieberman 2015. 
landowners still possessed lands at that time. ${ }^{25}$ Without localization, it is hard to know exactly which part or parts of the region saw a decrease in Jewish properties. If it seems immoderate to assume the total disappearance of Jewish landowners, this taqqanah associated with a responsum dating from the period of the gaon of Sura, Moses b. Jacob (g. 214-226 H/829-841 CE), can instead lead to the conclusion of a decrease in the numbers of small Jewish landowners. ${ }^{26}$

It is important to highlight that communal properties existed, ${ }^{27}$ as well as some sort of "religious institutional ownership". The revenue of the Geonic academies of Sura and Pumbedita partly derived from investments in real estate. ${ }^{28}$ In those cases, the landowners were an institution and not a particular person. It is also necessary to gain a better understanding of the lands owned by the Exilarchs, like those of the Bustanai family who monopolized this function over the entire period in question. ${ }^{29}$ Do we add them to lay landowners? Did they own their lands in a private capacity or did their lands relate to the Exilarchate?

\section{Christian/East Syrian Landowners}

The history of the Sasanian period shows that the East Syrian population in Lower Iraq was of ancient settlement; Kashkar was the oldest diocese known in the area. ${ }^{30}$ Two ecclesiastical provinces, Bēth Aramayē and Maysān, were noted in the region both during the Sasanian period and after the Islamic conquest. Our knowledge of the history of East Syrian population after that conquest is still incomplete.

In Lower Iraq, this lack of knowledge is partially because studies have mainly been made on the Church of the East and its catholicos ${ }^{31}$ or on monastic history. The lack of materials devoted to this region in comparison with what we are

25 A query addressed to Hayy Gaon (g. 939-1034) about "a Jew and a Gentile who took a field in partnership" (mentioned in Gil, 2004, 597; reference Toratān shel re's, II, 57 (no. 3)) and a query addressed to Naḥshōn Gaon (g. 872-879) about "a Jew who took a field from someone and his deed of sale was lost" (mentioned in Gil 2004, 598; reference Akargā: Resp. Sha'arē s, 53a (no. 53)).

26 Ackerman-Lieberman 2015, reference of the taqqanah: Lewin, VII, no. 531.

27 Morony 1984a, 313.

28 Brody 1998, 15, 39. On the last page, Brody refers to a letter giving an indication of these lands.

29 Goode 1940.

30 Fiey 1968, 151.

31 For example, Putman 1975. 
able to trace for al-Jazirra also explains the information gap. ${ }^{32}$ It is, however, important to recall the ground-breaking works of Jean-Maurice Fiey, ${ }^{33}$ who showed that it is possible to gain information about ownership of lands and landowners by leafing through chronicles or monastic histories. ${ }^{34}$ It is also possible to resort to the legal writings of Henanisho' (catholicos $65-73 \mathrm{H} / 685-693 \mathrm{CE}$ ), ${ }^{35}$ or to the ecclesiastical Regulations of Timothy I (catholicos 163-208 H/780-823 CE), ${ }^{36}$ which deal for example with inheritance law and monastic property and thus provide information about East Syrian landowners. East Syrian synods also need to be taken into account, especially regarding Church properties. ${ }^{37}$ This documentation demonstrates that landholding was meaningful at that time, and that land remained an important form of wealth. As Richard Payne wrote in an inspiring article: "Bishops and Christian landed elites[...] dominated Christian communities in Mesopotamia and Fārs on the basis of authorities, institutions and properties established during the Sasanian period[...]"38 This is confirmed by the primary sources.

At the very end of the $7^{\text {th }}$ century, much evidence about inheritance laws during the patriarchate of Henanisho' can be found in the letters sent to him and preserved in his Judgments. The case of Ahōnā is one such. Ahōnā came from Karka d-Beit and married, in addition to his legitimate wife, another woman in Ākōlā (=al-Kūfa). ${ }^{39}$ When he died, his sons solicited an episcopal ruling on whether or not the second wife was eligible to receive any inheritance. The letter provides indications of the landed property belonging to Ahōnā, who owned not only estates in Karka d-Beit but also in al-Kūfa. ${ }^{40}$ The decision taken by Henanisho' provides precious information about the conditions of private property.

One century later, catholicos Timothy I was also concerned with inheritance issues and monastic property, as we can see from the 45 paragraphs (§44 to §99) devoted to these matters in his Regulations for Ecclesiastical Judgments and In-

32 See the study of Robinson 2000.

33 Fiey 1968, 1980, 1990.

34 Among them: Zuqnīn Chronicle; İshō'dnah, The Book of Chastity; Thomas of Marga, The Book of Governors.

35 Henanisho', “Judgments”, in Sachau 1908, II, 1-51.

36 Timothy I, "Regulations”, in Sachau 1908, II, 54-117.

37 Chabot 1902.

38 Payne 2014, 4-5.

39 Karka d-Beit was located in al-Jazìra outside of Lower Iraq and is usually referred to as Karka d-Beit Slok according to Payne (2014, 4-5). I would like to thank Philip Wood who advised me about the existence of another Karka: Karka de Ledan in Khūzistān.

40 Henanisho', "Judgments", in Sachau 1908, II, 26-28. 
heritance. ${ }^{41}$ It also proves that there were still East Syrian landowners at that time. Timothy I begins his canonical rulings by explaining why he was late answering the demands of Jacob, the metropolitan primate of Maysān, and those of Rayy, Ḥabbībhā and many other laymen..$^{42}$ The East Syrian population were asking for regulation and the answer of the catholicos fulfilled that need. As far as inheritance law is concerned, it can be assumed that the ruling answered many problems encountered by East Syrian landowners, such as keeping estates within the community after the death of a male family head. The potential loss of estates after the death of one notable may also help to understand why paragraph $\S 57$ states that when a man or a woman had no heir, their inheritance was to be given to the Church. ${ }^{43}$ All these regulations may indicate changes that East Syrian landowners had to face in Lower Iraq during the $8^{\text {th }}$ century, and points out a concurrent decrease in non-Muslim Jewish and Christian landowners. It may also indicate an attempt by the East Syrian Church to enlarge its properties, since the question of unclaimed lands was also discussed by Muslim jurists.

Institutional ownership or ecclesiastical landholding-meaning lands belonging to the Church, including monastic property-were discussed in East Syrian legal documentation. There is no doubt that institutional ownership existed at that time; church and monastery estates were registered as early as $554 \mathrm{CE} .{ }^{44}$ The East Syrian Church, together with its monasteries, was an important landowner. In the Judgments of Henanisho' and in the Regulations of Timothy I, many cases related to monasteries. Paragraph $\S 78$ of the Regulations of Timothy I is about lands belonging to a deserted monastery. As there was no other monastery in the city, the question was whether the church of the city or a foreign monastery inherited the property of the deserted monastery. ${ }^{45}$ The rule does not apply to Lower Iraqi monasteries in particular but there were monasteries located in Lower Iraq, ${ }^{46}$ such as the monastery of Gabriel of Kashkar close to Dayr Qunnā in the village of Karsa ${ }^{47}$ or the monastery of Mār Sawrīsho' (Dayr Wāsiț). ${ }^{48}$

Some landowners within the Christian population cannot be regarded as regional landlords but rather as imperial or trans-regional landowners; Jibrīl Bukhtīshū' was one of them, as was the entire Bukhtīshū' family. Both his father

41 Timothy I, "Regulations”, in Sachau 1908, II, 88-115.

42 Timothy I, "Regulations”, in Sachau 1908, II, 56-57.

43 Timothy I, "Regulations”, in Sachau 1908, II, 96-97.

44 Morony 1981, 145.

45 Timothy I, "Regulations”, in Sachau 1908, II, 108-109.

46 As evidenced by the Kitāb al-Diyarāt, written by Muslim authors like al-Shābushtī (d. 988).

47 Fiey 1968, 170.

48 Fiey 1968, 171. 
and his grandfather were directors of the Jundīshāpūr academy in Iran. Jibrīl was first the physician of Yahyyā b. Barmak, then of Hārūn al-Rashīd, and finally of alAmīn. ${ }^{49}$ Thanks to Ibn Abī Ușaybi'a, author of 'Uyūn al-anmā' fi țabaqāt al-ațib$b \bar{a}^{\prime}$, we know that during the fratricidal war between al-Amīn and al-Ma'mūn, the houses and farms of Jibrīl in Baghdad, al-Bașra and al-Ahwāz were sacked. ${ }^{50}$ He thus owned properties in each of these areas. He also had multiple other estates, notably in his home region of Khūzistān.

It is also necessary to ask to what extent the East Syrian Church and its officials were imperial landlords.

\section{The Case of the Dahāqīn in Lower Iraq}

Dahāqin have to be added to the group of regional landowners in the same way as the previously named landowners. It is complicated to classify them as a nonMuslim group owing to the fact that a large number of them converted to Islam. ${ }^{51}$ However, we cannot exclude the possibility that some of them were Christian or Zoroastrian, before or after the Islamic conquest.

They represented regional landowners in the sense that they were tied to the land of this region. It is worth noting that during the Sasanian period, they could be regarded as imperial landowners because they were part of the Sasanian aristocracy-its lower caste, in charge of administration in the name of the Sasanian kings. They were also responsible for the collection of taxes and more generally were village heads. Not all of them were of Persian origin; we have found Aramaeans among them. ${ }^{52}$ As these Aramaean dahāqin were regional landowners and part of the Sasanian administration, they can be regarded as imperial elites as well. This again blurs the lines between specific types.

If the $7^{\text {th }}$ century can be seen as a golden age for the dahāqin, the $8^{\text {th }}$ century was the period of their decline as landowners. Initially they took advantage of the Islamic conquest to strengthen their administrative role on the one hand and their estates on the other. Their conversion to Islam might explain this, but not exclusively. In some cases, evidence indicates that they did not only keep their lands, but also enlarged their estates by absorbing some of the former

49 Putman 1975, 98-101.

50 Ibn Abī Usaybi'a, 'Uyūn al-anmā', 255.

51 Morony 1984a, 205.

52 For example Șalūba b. Nistūnā, who was lord of Quss al-Nātif and of most of the lands between the two branches of the Euphrates in the sawād of al-Ḥira (al-Balādhurī, Futūh, 245; alȚabarī, Ta'rīkh, III, 367). 
Sasanian crown lands. ${ }^{53}$ The beginning of the $8^{\text {th }}$ century was a turning point in their condition. As noted before, the upheaval of Ibn al-Ash'ath in 81-82 H/700 701 CE was important to the history of Lower Iraq and especially to the dahāqin who may have supported the rebellion. ${ }^{54}$ During this upheaval, the register of the Sasanian crown lands, which had been recovered under Mu'āwiya thanks to 'Abdallāh b. Darrāj, ${ }^{55}$ was burned. ${ }^{56}$ People then seized lands and made them their own.

This anecdote, reported by al-Balādhurī, may be indicative of the dahāqīn's desire to keep the land they had seized after the conquest-land the Umayyad state wanted to gain. The dahāqin had suffered from the suppression of the upheaval, a suppression whose repercussions were far-reaching. Some dikes were destroyed, making lands uncultivable, and al-Hajjāj refused to fix the irrigation system, a decision which most probably ruined the dahāqinn. ${ }^{57}$

Once again, this obvious decline may not have applied to the entire region of al-Sawād. Al-Ya'qūbī, who wrote his Kitāb al-Buldān during the $9^{\text {th }}$ century, explained that Dayr 'Aqul (not far from Nahrawān), Jarjarāyā and Mādarāya were all inhabited by Persian notables, specifying qawm dahāqīn ashrāf in the case of Dayr 'Aqul. ${ }^{58}$ In northeast Lower Iraq, there were thus still groups of landowners with Persian origins.

We must eventually discuss the relevance of the term dahāqin two centuries after the conquest, especially once the dahāqin converted to Islam. Some of those belonging to this group might have become henceforth part of the Muslim regional elites, quoted in the sources under their Muslim names without any clarification of their Sasanian background.

\section{Muslim Landowners: Between Regional and Imperial Elites}

By definition, the first Muslim landowners were originally part of the imperial elite. They did not come from Mesopotamia, but settled there in the course of the Islamic conquest and the founding of the amșār. These incoming imperial elites were the ancestors of the regionally born Muslim landowners who lived during the $8^{\text {th }}$ century, when the heirs of conqueror families can be counted

\footnotetext{
53 Al-Ya'qūbī, Ta’rīkh, II, 258.

54 Al-Balādhurī, Futūh, 293.

55 Al-Ya'qūbī, Ta’rīkh, II, 258; Al-Qāḍi 2006, 359.

56 Al-Balādhurī, Futūh, 272-273; Abū Yūsuf, Kitāb al-Kharāj, 1, 69.

57 Al-Balādhurī, Futūh, 293.

58 Al-Ya'qūbī, Kitāb al-Buldān, 1, 158.
} 
among Muslim landowners in Lower Iraq. This was, for example, the case of the family of Abū Bakra, ${ }^{59}$ one of the founders of al-Bașra, whose relatives were known as important landowners. ${ }^{60}$

The grandson of Abū Bakra, Bashīr b. 'Ubaydallāh b. Abī Bakra, was involved in conflicts related to land during the $8^{\text {th }}$ century. ${ }^{61}$ The family of Abu Mūsā al-Ash'arī, ${ }^{62}$ in particular his grandson Bilāl b. Abī Burda, was also part of the group of landowners in the area. ${ }^{63}$ The Banū l-Muhallab should additionally be taken into account during this period, especially Yazīd b. al-Muhallab and his close family.

By multiple means, Banū l-Muhallab and Yazīd became major landowners in Lower Iraq, but their territorial establishment was not limited to it. They forged ties in Khurāsān as well due to their government positions there. ${ }^{64}$ These regional Muslim landowners, tied to Lower Iraq since the Islamic conquest, participated in the working of the larger Islamic Empire by holding offices that brought them close to the imperial administration. The relation between government function and landholding is obvious since parts of the estates of these families were acquired by grants, ${ }^{65}$ so that imperial elites and regional landholding were intertwined. How regional landowners became eligible for government positions is also consistent. Thus, it was through their regional power and networks that they became imperial elites. This aspect of the explanation is strengthened by evidence proving that estates of these families were not only the result of grants but were also purchased. ${ }^{66}$ Nonetheless, participation in government does not alter the fact that these landowners were regional ones, with regional ties.

59 Pellat, “Abū Bakra”, $E I^{2}$, I, 14.

60 In Morony 1984b, 213, M. Morony gives, using al-Balādhurī’s Futūḥ, evidence of their estates in Lower Iraq.

61 With Yazīd b. al-Muhallab, who dug a canal in a land grant of Bashīr and then tried to pressure him into a document of title to this canal (al-Balādhurī, Futūh, 365); and also, under the governorate of Khālid b. 'Abdallāh al-Qasrī, with Hiimyarī b. Hilāl when Bashīr himself tried to gain the possession of part of his land grants by digging a canal (al-Balādhurī, Futūh, 364). 62 Lecker, “Abū Mūsā al-Ash'arī”, $E P^{3}$, http:// referenceworks.brillonline.com.ezproxy.univ-paris1.fr/entries/encyclopaedia-of-islam-3/al-ashari-abu-musa-COM_24243?s.num=1\&s.q=Abū+Mūsā+al-Ash'arī (accessed May 30, 2017).

63 Al-Balādhurī, Futūh, 353, 364.

64 Crone, "Yazīd ibn al-Muhallab", $E I^{2}$, VII, 361.

65 It is, for example, known that Yazīd b. al-Muhallab received as much of the swamps as he wanted from Sulaymān b. 'Abd al-Malik (al-Balādhurī, Futūh, 369).

66 Bilāl b. Abī Burda bought the land he then called Bilālān from 'Abbād b. Ziyād (alBalādhurī, Futūh, 353). 
Some elites owned lands in Lower Iraq but were not specifically tied to the region at first. In the case of al-Hajjāj b. Yūsuf or Khālid b. 'Abdallāh al-Qasrī, for example, the political careers of both indicate they have to be considered transregional elites. Their families were not specially bonded to Lower Iraq. ${ }^{67}$ Both became landowners in the area during their respective governorates. ${ }^{68}$ Khālid b. 'Abdallāh al-Qasrī lost most of his estates to caliphal confiscation following his dismissal, ${ }^{69}$ implying his landholding was linked to his government position. $^{70}$

The 'Abbāsid takeover and the shift of the center of gravity from Syria to Iraq impacted landowners and landholding in Lower Iraq. A study of Muslim landowners in the area during the first decades of the 'Abbāsid rule indicates an increase in those we can refer to as imperial landowners, in the sense that they were less tied to Lower Iraq and lived in Baghdad. ${ }^{71}$ This type of landlord was not entirely new, since the Umayyad family had owned large estates in Lower Iraq before.

Maslama b. 'Abd al-Malik was the landlord of important parts of al-bațā'ih. ${ }^{72}$ The caliph Hishām b. 'Abd al-Malik also acquired large estates through reclamation and development, ${ }^{73}$ though to a certain extent it remains unknown whether those estates were part of the șawāfi , the private property of the caliph, or both at the same time. The 'Abbāsid takeover was followed by the rise of non-regional landowners, mainly the 'Abbāsid family. Al-Manșūr possessed lands in Lower

67 Khālid b. 'Abdallāh al-Qasrī was, according to the prosopographic work of Crone 1980, 102, the grandson of a man who settled in Syria. His father is known to have participated to the battle of Marj Rāhit on the side of Ibn al-Zubayr. Khālid was governor of Mecca before his nomination in Iraq. As for al-Hajajāj b. Yūsuf, he was born in al-Tâa if in Arabia, where he spent his youth and where he is known to have been a teacher, participated in some battles and served as governor of Tabāla. He then moved to Syria, served in the shurța and began his rise in importance (Dietrich, "al-Hadjdjādj ibn Yūsuf”, $E I^{2}$, III, 41-45).

68 Khālid b. 'Abdallāh al-Qasrī (see al-Ṭabarī, Ta'rīkh, VII, 151-152; al-Balādhurī, Futūḥ, 290); al-Ḥajjāj b. Yūsuf (al-Balādhurī, Futūh, 289-90: in the course of the building of al-Wāsiț; Wakī', Akhbār al-quḍāt, II, 92-95: Sulaymān b. 'Abd al-Malik seized land belonging to the grandson of al-Ḥajjāj).

69 See al-Ṭabarī, Ta'rīkh, VII, 152

70 That Khālid owed his wealth to his governmental function is made quite clear in alBalādhurī's Ansāb al-ashrāf (IX, 31-109).

71 The question of absentee landlords is not broached here, but there is no doubt that in many cases these imperial landlords were rarely personally present. Even regional landowners may have lived in al-Bașra or al-Kūfa and managed their estates in the countryside at a distance. 72 Al-Balādhurī, Futūh, 294; Qudāma b. Ja'far, Kitāb al-Kharāj, 1, 169-70.

73 Al-Balādhurī, Futūḥ, 293; Qudāma b. Ja far, Kitāb al-Kharāj, 240; al-Ṭabarī, Ta'rīkh, VII, 142 143. 
Iraq. ${ }^{74} \mathrm{Al}$-Tabarī reported that the canal al-Khayzurāniyya was named after the 'Abbāsid caliph al-Mahdī's wife al-Khayzurān, and that another's name was derived from her secretary 'Umar b. Mihrān. ${ }^{75}$ It seems accurate to say that these were imperial, not regional, landowners.

Distinctions should be made when it comes to other members of the 'Abbāsid family, some of whom built links with Lower Iraq and settled there. One of the best examples is Sulaymān b. 'Alī, who in all probability settled in alBașra when he was appointed governor of the area. ${ }^{76} \mathrm{He}$ acquired a large number of estates through grants and irrigation projects and his son remained an important landlord in the area after him; they can be considered regional landowners. ${ }^{77}$ As in the Marwānid period, proximity to the caliph's family or government was a way to gain property under the 'Abbāsids; high officials were either granted numerous estates or purchased them. The case of Jibrīl Bukhtīshū' has been mentioned before, as has the Barmakids' case. As a matter of fact, these landowners-in comparison with the Marwānid period-were no longer regional landowners but rather settled in Baghdad or in other cities where they owned houses. They were typical trans-regional landowners.

It is important not to underestimate regional landowners. They did not disappear. Non-Muslim landowners were obviously still important. Yet as far as Muslim landowners are concerned, we can legitimately ask whether or not regional landlords were as important after the takeover of the 'Abbāsids.

The seizing of the Umayyad estates and the suppression of their supporters may have changed the pattern of landholding. New grants were given to regional elites ${ }^{78}$ like Sulaymān b. 'Ubaydallāh b. 'Abdallāh b. al-Hārith b. Nawfal, ${ }^{79}$ who received land from Abū l-'Abbās al-Saffāḥ in al-Bașra region. ${ }^{80}$ Some elites who had fallen into disfavor under the Umayyads managed to retrieve part of their lands after the 'Abbāsid takeover; the Muhallabī example is a striking one. ${ }^{81}$ In spite of some confiscation, a certain amount of Muslim landowners remained

74 Al-Balādhurī, Futūh, 362, 371-372.

75 Al-Ṭabarī, Ta’rīkh, IX, 491; Verkinderen 2018, 519-520.

76 He was first nominated in 133 H/751 CE (Ibn Khayyāț, Ta'rīkh, 412).

77 Al-Balādhurī, Futūh, 349, 369, 370 - 371. His son Muhammad, who inherited his fortune when he died in $173 \mathrm{H} / 789 \mathrm{CE}$, lost these estates when the caliph seized his fortune (al-Ṭabarī, Ta'rīkh, VIII, 237).

78 Who may have been supporters of the 'Abbāsid cause.

79 Sulaymān was an $a k h b \bar{a} r \bar{i}$, as we may note from al-Ṭabarī, and potentially from al-Saffāḥ’s reign. His grandfather 'Abdallāh (d. $84 \mathrm{H} / 703 \mathrm{CE}$ ) is said to have been a notable man settled in al-Bașra. He was governor of the city in $64 \mathrm{H} / 684 \mathrm{CE}$.

80 Wakī‘, Akhbār al-quḍāt, II, 92-95; Tillier 2009, 592-596.

81 Al-Balādhurī, Futūḥ, 367. 
on their lands, as indicated by al-Balādhurī regarding the estates named al-Masrukhānān. These belonged to the family of Abū Bakra. ${ }^{82}$ Some parts of them were confiscated by al-Manșūr, but the rest remained their property. ${ }^{83}$

The regional landowner elite was then composed of non-Muslim (mainly Jewish and East Syrian) as well as Muslim people. Two main differences existed between these two populations. The first group was of ancient settlement. After the Islamic conquest, they continued to own land. The second group only settled in Lower Iraq for about 50 to 60 years, and may be addressed in terms of generations since the first conquerors can be seen as imperial rather than regional elites. It is different for their sons, even more so for their grandsons. Two generations after the conquest, Muslim inhabitants of Lower Iraq had become elite regional landowners; they were born there and bonded to the area individually and sometimes professionally.

The second difference between the two populations is in their relationship with the Islamic Empire. The Muslim regional elites often played a role in the working of the Empire and in that respect were regional as well as imperial elites. There was apparently a link between governing and landholding, since parts of the estates of these Muslim families were acquired by grants. To a certain extent, the imperial role taken on by regional elites might also be applied to the non-Muslim group, for example the ecclesiastical elites (particularly at the highest level of the Exilarch and catholicos).

These sample types of landowners in Lower Iraq are put forward to single out relevant categories for the study of landholding, landowners and more generally for the history of Lower Iraq during the $8^{\text {th }}$ century. These types should not however be considered completely accurate without a study of the location of specific estates. Grants were often located in the al-Bașra area or in swamps. The lands around al-Kūfa were mainly owned by Jews and those around Wāsit by East Syrians. This study of estate locations is difficult to carry out at scale but it is certainly useful regionally. The interplay between the diverse groups of landowners defined here aids in grasping the changes that occurred in the course of the $8^{\text {th }}$ century, and helps the work of localization. The different modalities and interactions also help to explain the power ratios at stake at that time in Lower Iraq.

82 Al-Balādhurī, Futūḥ, 365.

83 Al-Balādhurī, Futūḥ, 365. 


\section{Interplays}

By interactions, I do not only mean inter-group relationships; intra-group ones must also be considered. Types are inaccurate when not associated with a study of their interactions. As far as landowners are concerned, these examples of interplay may be distinguished in three ways. The first is related to the acquisition of estates, the second to the loss of properties. The last stems from conflicts over land; these were sometimes linked to the purchase of estates. These three aspects of interaction sometimes became entangled.

\section{Acquiring an Estate}

Most people involved in purchasing land during the $8^{\text {th }}$ century were Muslim landowners. Non-Muslim landowners already owned lands at the time of the conquest and in the main their heirs inherited them. The inheritance of estates may be part of the acquisition of lands, but only passively. Non-Muslim landowners were not marginalized and certainly purchased lands on occasion, but the fact remains that written sources contain more information about Muslim landowners. According to the available materials, one of the first ways to become a landowner was related to land grants. This type of acquisition did not necessarily entail an interaction between two persons or two groups, as in (for example) land reclamation.

\section{Land Grants}

Land grants are one of the main interactions regarding land purchase, linking imperial elites-primary the caliphs-to regional elites. Those receiving land during the $8^{\text {th }}$ century were mainly high officials (governors, qudāt, shurța chiefs) or relatives of the caliphs and mawālì. Al-Balādhurī can be singled out as one of the main authors providing information regarding these grants. ${ }^{84}$ Although the source is rather recent, al-Balādhurī notably ${ }^{85}$ used the works of al-Qahdhami as a source. ${ }^{86} \mathrm{Al}$-Qaḥdhamī was a Bașran akhbārī whose grandfather Qạ̣dham was a financial secretary and/or in charge of the tax office in Iraq under al-Hajjāj

84 This information was found through al-Balādhurī’s Futūh al-Buldān.

85 Al-Balādhurī used 35 pieces of information from this akhbārī in the section about al-Bașra. 86 See the article of al-Qāḍī 2010, 258-266. 
b. Yūsuf, Khālid b. 'Abdallāh al-Qasrī and Yūsuf b. 'Umar al-Thaqafī. ${ }^{87}$ He may have transmitted information whose authority was based on some lost government archive.

Literature about these land grants shows they are an interesting matter that is worthy of discussion. ${ }^{88}$ For my purposes, this is primarily in terms of the interplays that land grants broached. Thanks to the qața' $i$ ', grantees became landlords of their estates with full ownership. ${ }^{89}$ Land grants could be associated with land reclamation, ${ }^{90}$ but such reclamation was also possible during the $8^{\text {th }}$ century without a grant.

Land grants established an interaction between two groups: the granter and the grantee/receiver. For Islamic landowners, land grants can be seen as the primary way to acquire land, via a method implying a relationship with the caliph. Such relationships were inter-group as well as intra-group: caliphs granted land to regional officials and local notables (regional elites), ${ }^{91}$ especially during the Marwānid period, but also gave estates to relatives and mawālì (imperial elites). ${ }^{92}$ I must emphasize the continuation of grants under 'Abbāsid rule to members of the 'Abbāsid family ${ }^{93}$ and 'Abbāsid followers, ${ }^{94}$ especially important figures of the central government; that may indicate a rise of intra-group grants within imperial elites.

\section{Buying Land}

The purchase of lands was another way to become a landowner, one that plainly implies an interaction between the buyer and the seller. This interaction adds the seller to the group of those losing land, while for the buyer the purchase is a way

87 al-Qāọī 2010, 264-265.

88 For example Morony 1984b; Kennedy 2004, 2014; Verkinderen 2018.

89 It is debatable, but I argue that at that time the qațā $\bar{\imath}$ meant a grant of landownership. See

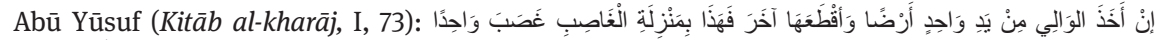
وَأَعْطَى آخَرَ

90 About land reclamation see Verkinderen 2018.

91 For example, Yazīd b. 'Abd al-Malik granted 'Umar b. Hubayra land seized from Yazīd b. alMuhallab (al-Balādhurī, Futūh, 367).

92 Hishām b. 'Abd al-Malik granted some of the land confiscated from Yazīd b. al-Muhallab to his son (al-Balādhurī, Futūh, 369).

93 This was for example the case of Sulaymān b. 'Alī, who was granted the estate called 'Abbāsān by Abū l-'Abbās (al-Balādhurī, Futūḥ, 369).

94 Yaqtịn șāhib al-da'wa-who was certainly Yaqțin b. Mūsā-received several diya'as in alSawād in the early period of the 'Abbāsid caliphate (Qudāma b. Ja'far, Kitāb al-Kharāj, I, 17; about Yaqțin, see also Elad 1992, 315-316). 
to join the group of those who own an estate. There is evidence of a real-estate market in the sale of land between Muslim elites. Bilāl b. Abī Burda, for example, is known to have had acquired the estate of 'Abbād b. Ziyād in this way, ${ }^{95}$ among other tracts of land. ${ }^{96}$ According to Khālid b. 'Abd al-'Azīz al-Thaqafī, Wakī' also reported that Yahyā b. Barmak bought land close to al-Bașra from Hārūn al-Rashīd. ${ }^{97}$ In the Kitāb al-Wuzarā', Ibrāhīm al-Mawșilī, a famous singer close to Hārūn al-Rashīd, is recorded as wanting to buy the estate ( day $^{\prime} a$ ) next to his, up for sale at 100,000 dirhams. ${ }^{98}$

As far as these examples are concerned, the purchase created an intra-group relationship within the Muslim group of landowners. In the case of Bilāl b. Abì Burda and 'Abbād b. Ziyād, the interaction was established within the regional group of Muslim landowners. In that of Yahyā b. Khālid al-Barmakī and Hārūn al-Rashīd, it happened within the imperial group. Despite this, there is nothing to preclude the purchase of lands between non-Muslim and Muslim groups, though there is no extant evidence of it over the course of the $8^{\text {th }}$ century in Lower Iraq. Legal sources composed at the end of the $8^{\text {th }}$ century do indicate some examples of selling of lands following the Islamic conquest, and provide interesting information devoted to the question of kharāj lands and transactions between ahl al-kitāb and Muslims. ${ }^{99}$ The fact that the jurists found it important to broach this theme shows that some Muslim elites must have bought land from non-Muslim elites.

The market did not represent the principal interaction between groups of landowners. Land purchase was not the main way of gaining an estate, especially from the end of the century when legal sources began to forbid (up to a point) the purchase of kharāj lands. This ban may be understood as a way for the 'Abbāsid rulers to keep control of the land market and avoid the reduction of taxes.

It may be possible to connect the normative decision formulated in these sources with another way to acquire land.

95 He was one of the four sons of Ziyād b. Abīhi.

96 Al-Balādhurī, Futūḥ, 353: 'Abbād b. Ziyād's land is called qați' āa, indicating he received it as grant. It attests that the grantee was allowed to sell his grant.

97 Wakī‘, Akhbār al-quḍāt, I, 143.

98 Al-Jahshiyārī, Kitāb al-Wuzarā', 214.

99 For this matter see, in their respective English translations: Ibn Sallām from tradition 194 to 230 dealt with “The purchase of lands annexed by force...”; Yahyā b. Ādam collected 57 traditions (136-193) about "The ban of the purchase of kharāj lands". 


\section{Talji'a and Ḥimāya: A Process of Purchasing Land?}

Interactions between landowners regarding the purchase of land include what have been called talji' $a$ and himāya. These concepts refer to habits and institutions of protection more or less unknown by the fiqh, even though they seemed important in Islamic society. The talji' $a$ indicates an interaction concerning the acquisition of land as well as its loss. It is particularly noteworthy since on the one hand it connects groups with each other but not necessarily within themselves, and on the other it contributes to the decrease in small landowners in Lower Iraq-perhaps specifically to the decrease in non-Muslim landowners.

The talji' $a$ referred to a process via which an independent landed proprietor asked for protection (himāya), or more precisely placed his land under the protection (alja'a) of a bigger landowner. This protector was then registered in the fiscal dīwān, preserving the smaller landowner from extortion. The protégée, who had secured himself and indemnified his estates, had to provide financial compensation to the protector in addition to the usual taxes. ${ }^{100}$ The definition given by al-Khwārizmī in Mafātīh al- 'ulūm does not say anything about this compensation, though. ${ }^{101}$ In the chapter devoted to secretaryship (al-kitāba), in the section on the technical terms used by the secretaries in the dīwān al-kharāj, the talji' $a$ is defined as "when a weak person hands over (yulji'a) his property $\left(\right.$ day $\left.^{\prime} a\right)$ to a strong one so that the latter may protect it. Plurals for the word are maläji' and taläji'. The strong person usually protects the property which its owner (șâhib) has entrusted to him."102 Even if financial compensation is not mentioned, the fact that during the $10^{\text {th }}$ century the talji' $a$ was considered one of the technical terms a secretary of the diwān al-kharāj needed to know and understand suggests that it was a custom at that time.

The process of talji'a was not limited to Lower Iraq. Evidence of it can be found in Fārs, Khūzistān ${ }^{103}$ and even further-Mafātīḥ al-'ulūm may have been dedicated to a Sāmānid wazīr of Nīshāpūr. ${ }^{104}$ In Khūzistān, a landlord from alAhwāz asked Abū Ayyūb, a secretary of al-Manșūr, ${ }^{105}$ to register the landlord's estate under his name in order to protect him from the 'ummāl in exchange for 100,000 dirhams every year. ${ }^{106}$ As far as the south of Iraq is concerned,

100 Cahen, "Himāya”, $E I^{2}$, III, 406-407; Lokkegaard 1950, 67-68.

101 Al-Khwārizmī, Mafātīḥ al-'ulūm, 73.

102 Translation of Bosworth 1969, 138.

103 Fārs: al-Ișțakhrī, Kitāb Masālik al-mamālik, 158; Khūzistān: al-Jahshiyārī, Kitāb al-Wuzarā', 118.

104 Sabra, “al-Khwārizmī”, $E I^{2}$, IV, 1100 -1101.

105 Sourdel 1960, 1, 78-87.

106 Al-Jahshiyārī, Kitāb al-Wuzarā', 118. 
one of the most striking examples of the talji' $a$ is recorded in al-Balādhurī's Futūḥ al-buldān and concerns Maslama b. 'Abd al-Malik. ${ }^{107}$ At the beginning of the $8^{\text {th }}$ century, under the governorate of al-Hajjāj and the reign of al-Walid, Maslama is known to have invested 3,000,000 dirhams in the restoration of an irrigation system and in return gained possession of certain lands. ${ }^{108}$ Many landowners are said to have voluntarily turned their lands over to him. ${ }^{109}$ Some evidence can also be found in the first 'Abbāsid decades, when according to al-Tanūkhī a landowner offered al-Manșūr 25 percent of the products of his land in addition to the usual tax provided that the caliph registered the land under his own name. ${ }^{110}$ In al-Jazira, the author of the Chronicle of Zuqnin explained that around 155-163 H/772-779 CE, some landowners/farmers sought protection from local chiefs. ${ }^{111}$ These few examples are representative of the implicit relationship in the talji'a: between the one seeking protection and the protector, or between the small landowner and the larger.

These examples also make it possible to understand two of the reasons explaining the cause of the process. The himāya of Maslama needs to be contextualized. Because of the upheaval of Ibn al-Ash'ath, damage was done to the dikes that grew worse. It is possible to link this and the demand of al-Hajjāj to al-Walid..$^{112}$ In that case, the talji' $a$ may be related to the caliphal refusal to take over upkeep and the subsequent recourse to a private investor in the person of Maslama. The small landowners seeking himāya might have been in a difficult economic situation (perhaps with uncultivable lands).

The other two examples, plus that of Khūzistān, are quite different. They refer to the harsh tax-levy and its excesses, especially those of the tax collectors. ${ }^{113}$ They are representative of the reasons behind the talji' $a$, at least at the beginning of the 'Abbāsid period. Epistles dedicated to al-Manșūr and alMahdi condemn this harsh tax-levy as well as the abuses of the tax collectors. So much can be read in the Risālat al-ṣahāba composed by Ibn al-Muqaffa' for al-Manșūr, ${ }^{114}$ and in the Risāla addressed to al-Mahdī by 'Ubaydallāh b. alHasan al-'Anbarī, who was qāẹi of Baṣra between 156 H/773 CE and 166-167

107 Al-Balādhurī, Futūh, 294; Qudāma b. Ja'far, Kitāb al-Kharāj, I, 169-70.

108 Al-Balādhurī, Futūḥ, 294.

109 Al-Balādhurī, Futūḥ, 294; in Arabic: وعر نلك الارضين والجأ الناس اليها ضياعا كثيرة للتعزّز به

110 Al-Tanūkhī, Nishwār, VIII, 76.

111 Chronicle of Denys of Tell Mahré, 138.

112 Al-Balādhurī, Futūh, 294.

113 Chronicle of Denys of Tell Mahré, 138, and al-Tanūkhī, Nishwār, VIII, 76.

114 Ibn Muqaffa', Risāla, 117. 
H/782-784 CE. ${ }^{115}$ The consequences of the 'Abbāsid tax policy on landholding patterns ${ }^{116}$ may explain why the process still went on in the $10^{\text {th }}$ century and thus be part of the explanation of the lessening of small landholding after all.

In terms of interplays, the talji'a created interesting relationships between the groups of the typology. No indication is provided regarding those who turned their estates over to Maslama. Knowing that it took place in Lower Iraq at the beginning of the century, it can be assumed that the protégées were either from groups of non-Muslim landowners or the dahāqin (whether Muslim or not). The hypothesis of the dahāqin using this seems likely because of the difficulties they faced at the time. ${ }^{117}$ In the Jaziran example, there is no doubt that the landowners asking for protection were Christians. ${ }^{118}$ As far as the village chiefs are concerned, we can also assume that they were a part of the Christian population if we follow Chase F. Robinson's discussion of the shahārija. ${ }^{119}$ It corresponds to an intra-group relationship or an inter-group one. The al-Manșūr case is more complicated but as in Maslama's example it was an inter-group meeting between imperial and local elites.

Why can talji' $a$ be added to the process of purchasing lands? Strictly speaking, the protected individual should have remained the owner of his estates. This was a subject of debate between academics who wrote about talji'a and himāya. ${ }^{120}$ This agreement was unstated, and the name of the original owners was removed from the tax register-meaning that it could become impossible for them to establish actual ownership. According to Claude Cahen and Ḥusām al-Sāmarrāie, what was at first joint property became, as time passed, the property of the protector. The original landowner was reduced to a share-

115 Tillier 2006, 147-148, 162.

116 Ackerman-Lieberman 2015, online. The question of the consequences of the 'Abbāsid tax policy can also be related to the promotion of a new assessment system in al-Sawād, the muqūsama. On this question, see for example Campopiano 2011.

117 See above regarding the dahāqin and the refusal of al-Hajjāj to fix irrigation infrastructures. 118 The Chronicle of Zuqnin/Chronicle of Denis of Tell Mahré deals with the Christian population.

119 According to Robinson 2000, 90 -108, the name shahārija was given to some local notables who were part, like the dahāqin, of the nobility of al-Sawād during the Sasanian period. They were however superior in rank to the dahāqin.

120 Claude Cahen and Fred Lokkegaard seem to disagree, since Lokkegaard wrote that "On entering the talji' $a$ the one who cedes his day'a loses his milk in it” $(1950,68)$ and Cahen thought that the protégée remained the official owner of his land but lost real control of it over time (Cahen, "Ḥimāya”, $E I^{2}$, III, 406-407). 
cropper. ${ }^{121}$ This observation may be corroborated by the use of the term muzā$r^{\prime}$ ' $\bar{n}{ }^{122}$ For the protectors, the talji' $a$ was a way to gradually purchase land.

The use of talji' $a$ as a way to protect property may explain the decrease in numbers of small landowners, especially among the non-Muslim groups, or rather their drop in status to estate share-croppers rather than owners. It is not a coincidence that fiqh literature about contracts, and especially all types of sharecropping contracts, is fairly developed even when talji' $a$ is still unknown by the fiqh. ${ }^{123}$ Since precise examples of talji ' $a$ are scarce, it was either not a very extensive phenomenon, or practically speaking it referred to share-cropping or a similar contract. The latter may also explain why the talji' $a$ was an unstated agreement since the rules governing share-cropping were strict in fiqh literature. The links between talji' $a$ and share-cropping need further study in order to better understand the difference between ownership and possession of an estate. The scope of the phenomenon needs to be properly reckoned since narratives give little evidence of the talji' $a$ as such.

The fact remains that the talji' $a$ may be regarded as part of a process leading to the loss of an estate.

\section{The Loss of Estates}

Losing an estate is the other side of the transaction, whether via selling or the talji'a. Some loss of estates might also be related to inheritance. The heirs of a landowner inherited his estates. Without heirs, notably without sons, various issues emerged regardless of the concerned landowner group. ${ }^{124}$ Questions of inheritance will not be tackled in the course of this paper; I will rather concentrate on the seizure of estates, which reflects an important power dynamic of the time.

The confiscation of estates occurred frequently during the $8^{\text {th }}$ century. It could only happen as part of an unequal relationship. The power to seize land was the exclusive preserve of the supreme authority, the caliph. Even leaving out the massive confiscation of Umayyad landed estates carried out immediately following the takeover of the 'Abbāsids, land seizure remains significant. New landlords were promoted whereas others lost their lands. Lands owned by Maslama b. 'Abd al-Malik, ${ }^{125}$ for example, were confiscated by the 'Abbāsids and

121 al-Sāmarrāie 1972, 131; Cahen, "Ḥimayā", $E I^{2}$, III, 406-407.

122 Cahen 1956, I, 273.

123 See al-Ṭabarī, Kitāb Ikhtilāf al-fuqahā', 141-170.

124 See above regarding Jewish and Christian landowners.

125 And in the course of which some farmers asked for protection. 
granted to Dā'ūd b. 'Alī b. 'Abdallāh b. al-'Abbās, a brother of Sulaymān b. 'Alī. ${ }^{126}$ The seizing of Umayyad lands took place in a characteristic context. What must be remembered is the 'Abbāsid action of confiscation was not only limited to the takeover period and to Lower Iraq. It may be regarded as an 'Abbāsid policy, "a general process encompassing the entire caliphal domains." 127

A pattern can be seen in the cases of confiscation described during the Marwānid and the 'Abbāsid periods. The seizing of land points out interplays between imperial elites and regional elites as well as within imperial groups. Both instances take place within the Muslim group of landowners who work as high officials for the Islamic Empire. There are multiple cases among them, including the confiscation of the Muhallabid estates as a result of the upheaval of Yazìd and his suppression ${ }^{128}$ and the seizing of the possessions of Khālid b. 'Abdallāh al-Qasrī after his dismissal. ${ }^{129}$ During the 'Abbāsid $8^{\text {th }}$ century, there is the confiscation of Muhammad b. Sulaymān b. 'Alī l-'Abbāsī's estates after his death ended his governorate in al-Bașra, ${ }^{130}$ and the seizing of the Barmakids' estates. ${ }^{131}$ In each case, seizure took on the guise of punishment and was added to a set of other sentences. ${ }^{132}$ Seizure was the most relevant because it linked caliphal policies of centralization and land control. Seizing these estates meant properties gained by the caliphal authority swung the balance of power in the state's favor. It may even be indicative of a formal state policy designed to monopolize as much land as possible in the strategic region of Lower Iraq. Land remained an essential basis of wealth. ${ }^{133}$

126 Al-Balādhurī, Futūh, 294.

127 Elad 2016, 103.

128 Al-Balādhurī, Futūh, 369.

129 Al-Ṭabarī, Ta'rīkh, VII, 152.

130 Al-Ṭabarī, Ta'rīkh, VIII, 237.

131 Al-Ṭabarī, Ta’rīkh, VIII, 296; al-Jahshiyārī, Kitāb al-Wuzarā', 237-293.

132 Yazīd was accused of rebelling against the caliphate. Khālid b. 'Abdallāh al-Qasrī was accused of embezzlement or at least of the fraudulent acquisition of his fortune. Muhammad $b$. Sulaymān b. 'Alī did not comply with Hārūn al-Rashīd's orders, especially regarding the appointment of judges (Tillier 2009, 109-111). As for the Barmakids, the reasons behind their disfavor are not yet clear.

133 In this respect, the article of Albrecht Noth, "Some Remarks on the Nationalization of Conquered Lands at the Time of the Umayyads” (1984, 227-228), is inspiring since he reaches a similar conclusion from the study of șulhan/'anwatan traditions in the Iraqi sawād. According to him, these traditions date to the period between the end of the $7^{\text {th }}$ and the beginning of the $8^{\text {th }}$ centuries. Thus they may reflect a power struggle between the Umayyad government, which tried to claim as much 'anwatan land as possible, and the descendants of the conquerors, who had become landowners and wanted to claim to as much șulhan land as they could. 


\section{Contentious Interplays}

While land was a debated legal matter, as may be read in the various Kitāb alKharāj, it was also at the heart of conflicts between landowners in Lower Iraq during the $8^{\text {th }}$ century. One may say that it even generated those conflicts, or at least led to contentious relationships. In line with Georg Simmel's theory about conflicts, these troubled interplays should not only be seen as creators of opposition between groups, but also perceived as an interaction forming links.

Lands could be passed down via inheritance and were an important source of wealth. For that reason competition over who inherited land was fierce following the death of the primary male householder. The Judgments of Henanisho' contain many typical inheritance questions and their resolutions. In Ahōnā's case, ${ }^{134}$ the question asked is whether or not his second wife in al-Kūfa was allowed to inherit something when he already had a wife and children. ${ }^{135}$ In other words, the sons of Ahōnā spoke out against their father's second wife. In this case, in the end the whole inheritance reverted back to the legitimate widow and the sons, but the second wife "received an estate" as a residence and source of income for her lifetime. ${ }^{136}$ This story is not an isolated case. Others like it can be observed in the Judgments of Henanisho' and also in the Regulations of Timothy I. ${ }^{137}$ These troubled interactions happened among East Syrian landowners but it is not hard to imagine that similar conflicts existed within the groups of Jewish or Muslim landowners. The question is, to what extent were issues of land inheritance the subjects of lawsuits or of legal resolution? The existence of troubled interactions due to inheritance issues regarding lands is highlighted in this work, and all the questions around it are still an ongoing subject for research.

Other conflicts arose from individuals who opposed each other over ownership of land or its fraudulent purchase. One example of a conflict over land in Lower Iraq in the course of the $8^{\text {th }}$ century is the case of Bashīr b. 'Ubaydallāh b. Abī Bakra and Hiimyarī b. Hilāl, which occurred under Khālid b. 'Abdallāh al-Qasrī’s governorate in Iraq. Hiimyarī b. Hilāl blamed Bashīr for attempting to gain possession of some of his estates ${ }^{138}$ by digging the al-Murghāb

134 Henanisho', "Judgments", in Sachau 1908, II, $26-28$.

135 Henanisho', "Judgments", in Sachau 1908,II, 2-28.

136 Henanisho', "Judgments”, in Sachau 1908, II, 26-28.

137 See for example Henanisho', "Judgments", in Sachau 1908, II, 18 - 21 and 22-23; Timothy I, "Regulations", in Sachau 1908, II, $90-93$.

138 His estates actually belonged to his father and had been granted to him by Yazīd b. 'Abd alMalik. 
canal. ${ }^{139}$ This troubled relationship between two local landowners shows the depth of competition for the ownership of land at that time. Bashīr, who is known to have been an important landowner, sought to increase his estates. This example also shows that the building of canals and dikes was not only vital for agriculture but might also have been a way to gain possession of land.

Some conflicts are specifically linked to land grant issues. This is true of the case under al-Mahdì’s reign between Muhammad b. Sulaymān al-Nawfalī, whose grandfather received a land grant from Abū l-'Abbās al-Saffāḥ, and the Banū 'Abd al-Malik, whose ancestors owned estates granted at the time of the Marwānids until Sulaymān b. 'Abd al-Malik seized them. ${ }^{140}$ During al-Mahdī's reign the Banū 'Abd al-Malik tried to reclaim the land their ancestors had lost. They resorted to being helped by the qā $\bar{c} \bar{l}$ and trying to charge Muhammad b. Sulaymān alNawfalī with acquiring their land by force (ghașabahum). ${ }^{141}$ Details of such troubled interplays are not necessarily useful here, but the conflict is a good illustration of the complexity and consequences of confiscation and ownership. It also points out issues that might have been raised after the 'Abbāsid takeover and their redistribution of the Umayyad estates.

The landowner point of view offers a relevant angle to grasp the diversity of Lower Iraqi elites. This variety can be couched in terms of religion and also in ties to the larger Islamic Empire. The distinction between regional and imperial or trans-regional landowners is inspiring but needs to be further discussed. The presentation of interactions between group types helps to understand the nature of the relationships that existed between the different groups of landowners. At the same time, it enables an understanding of the power ratio between various Lower Iraqi landowners, and between them as a group and the caliphal state.

This attempt to describe Lower Iraqi landowners is not only useful in gaining a better view of Lower Iraqi society during the $8^{\text {th }}$ century. It also sheds a light on the multiple processes that disrupted or changed the workings of this empire and its society, such as the decreasing numbers of small landholders. The role of the imperial state in all this has now been sketched, but still needs to be studied.

139 Al-Balādhurī, Futūh, 364.

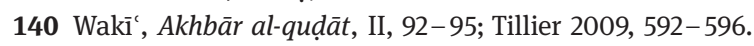

141 Wakī‘, Akhbār al-quḍāt, II, 93-94. 


\section{Bibliography}

\section{Primary Sources}

\section{Islamic}

Abū Yūsuf, Ya'qūb b. Ibrāhīm (1979), Kitāb al-Kharāj, ed. n.n, Beirut: Dār al-ma'rifa; 1984 edition by Maḥmūd al-Bājī, Tunis: Dār Bū Salāma li-l-țibā'a wa-l-nashr wa-l-tawzī'; trans. by E. Fagnan (1921), Le livre de l'impôt foncier, Paris: Geithner; trans. by A. Ben Shemesh (1965-69), Taxation in Islam, vol. 3: Abū Yūsuf's Kitāb al-Kharādj, Leiden: Brill.

al-Balādhurī, Aḥmad b. Yaḥyā (1866), Kitāb Futūḥ al-buldān, ed. by M. J. de Goeje, Liber expugnationis regionum, Leiden: Brill.

al-Balādhurī, Aḥmad b. Yaḥyā (1996), Ansāb al-Ashrāf, vol. IX, ed. by Suhayl Zakkār and Riyāọ Ziriklī, Beirut: Dār al-fikr.

Ibn Ādam, Yaḥyā (1927), Kitāb al-Kharāj, ed. n.n, Cairo: al-Mațba'at al-salafiyya wa-maktabatuhā; trans. by A. Ben Shemesh (1958), Taxation in Islam, vol. 1: Yahyā ben Adam's Kitāb al-Kharādj, Leiden: Brill.

Ibn al-Muqaffa' (1976), Risālat al-Șahāba, ed. and trans. by Charles Pellat, Ibn al-Muqaffa' (mort vers 140/757) “conseilleur" du calife, Paris: Maisonneuve et Larose.

Ibn Rusta, Abū 'Alī Aḥmad b. 'Umar (1892), Kitāb al-A'lāq an-nafīsa, ed. by M. J. de Goeje, Kitāb al-a'lāk an-nafissa VII / auctore Abū Alī Ahmed ibn Omar Ibn Rosteh et Kitāb al-boldān / auctore Ahmed ibn abī Jakūb ibn Wādhih al-Kātib al-Jakūbī, Leiden: Brill.

Ibn Sallām, Abū 'Ubayd al-Qāsim (1981), Kitāb al-Amwāl, ed. n.n., Beirut: Dār al-fikr; trans. by I. A. Khan Nyazee (2003), Abū 'Ubayd al-Qāsim ibn Sallām. The Book of Revenue: Kitāb al-Amwāl, London: Garnet Publishing Limited.

al-Iștakhrī, Abū Ishāq Ibrāhīm b. Muḥammad al-Fārisī (1870), Kitāb al-Masālik wa-l-mamālik, ed. by M. J. de Goeje, Viae regnorum: descriptio ditionis moslemicae, Leiden: Brill.

al-Jahshiyārī, Abū 'Abdallāh Muḥammad b. 'Abdūs (1938), Kitāb al-Wuzarā' wa-l-kuttāb, ed. by 'Abd al-Ḥamīd Ạ̣mad Ḥanafī, Cairo.

Ibn Khayyāṭ al-'Ușfurī, Khalīfa (1967), Ta'rīkh, ed. by Akram Ḍiyā' al- UUmarī, Najaf: Mațba'at al-adāb.

al-Khwārizmī, Abū 'Abdallāh Muḥammad b. Aḥmad (1991), Mafātīḥ al-'ulūm, ed. by Jawdat Fakhr al-Dīn, Beirut: Dār al-manāhil.

Qudāma b. Ja'far, Abū l-Qāsim (1981), al-Kharāj wa-șinā'at al-kitāba, ed. n.n., Baghdad: Dār al-rashīd li-l-nashr.

al-Shābushtī, Abū l-Ḥasan 'Alī b. Muhammad (2008), The Shabushti’s Book of Monasteries: al-Diyarāt, ed. by George Awwad, Piscataway: Gorgias Press.

al-Ṭabarī, Abū Ja'far Muḥammad b. Jarīr (1968), Ta'rikh al-rusul wa-l-mulūk, ed. n.n., 11 vols., Beirut: Dār al-turāth.

al-Ṭabarī, Abū Ja'far Muḥammad b. Jarīr (1999), Kitāb Ikhtilāf al-fuqahā’, ed. n.n., Beirut: Dār al-kutub al-ilmiyya.

al-Tanūkhī, Abū 'Alī l-Muḥassin b. 'Alī (1971-1973), Nishwār al-muḥạ̣̄ara, ed. by 'A. Shalji, Beirut: 'Ālam al-kutub.

Wakī', Muḥammad b. Khalaf (1947-1950), Akhbār al-quḍāt, ed. by 'Abd al-'Azīz Mușțafā al-Marāghī, 3 vols., Cairo: Mațba'at al-sa'āda. 
al-Ya'qūbī, Abū l-'Abbās Aḥmad b. Abī Ya'qūb (1969), Ta'rīkh, ed. by M. Th. Houtsma, Historiae, 2 vols., Leiden: Brill.

\section{Christian}

Chronique de Denys de Tell Mahré (=Chronicle of Zuqnīn) (1895), trans. into French by J.-B. Chabot, Part IV, Paris: Emile Bouillon; trans. into English by Amir Harrak (1990), The Chronicle of Zuqnīn, Part III. And IV., AD. 485-775, Toronto: Pontifical Institute of Medieval Studies.

Chabot, Jean-Baptiste (1902), Synodicon Orientale ou recueil des synodes nestoriens, Paris: Imprimerie nationale.

Ibn Abī Usaybi'a, Muwaffaq al-Dīn Abū l-'Abbās Aḥmad b. al-Qāsim b. Khalīfa b. Yūnus al-Khazrajī (1971), 'Uyūn al-anmā' fi țabaqāt al-ațibba, trans. by L. Kopf, History of Physicians, Jerusalem: The Hebrew University, Institute of Asian and African Studies.

Īshō'dnah (1896), The Book of Chastity, ed. and trans. by J.-B. Chabot, "Le livre de la Chasteté composé par Jésusdenah, Évêque de Baçrah, publié et traduit par M. J.-B. Chabot", Mélandes d'archéolgie et d'histoire 16, 225-291.

Mārī b. Sulaymān (1896-99), Kitāb al-Majdal, in: H. Gismondi, Maris, Amri et Slibae de patriarchis Nestorianorum commentaria, Rome: EDI.

Sachau, Eduard (1908), Syrische Rechtsbücher, vol. 2: Richterliche Urteile des Patriarchen Chenânîschô, Gesetzbuch des Patriarchen Timotheos, Berlin: G. Reimer.

Thomas of Marga (1893), The Book of Governors, ed. and trans. by E. A. Wallis Budge, London: Kegan Paul/Trench-Trübner\&Co.

\section{Jewish}

Lewin, Benjamin (1928-1945), Oșar ha-Geonim, Jerusalem: Mosad ha-Rav Kuk. Neubauer, Adolf (1887-95), Mediaeval Jewish Chronicles and Chronological Notes, 2, Oxford: Clarendon.

\section{Studies}

Ackerman-Lieberman, Phillip I. (2015), "Revisiting Jewish Occupational Choice and Urbanization in Iraq under the Early Abbasids”, Jewish History 29: 130-135.

Bosworth, Clifford E. (1969), "Abū 'Abdallāh al-Khwārazmī on the Technical Terms of the Secretary's Art: A Contribution to the Administrative History of Mediaeval Islam”, Journal of the Economic and Social History of the Orient 12/2: 113-164.

Brody, Robert (1998), The Geonim of Babylonia and the Shaping of Medieval Jewish Culture, New Haven: Yale University Press.

Cahen, Claude (1953), "L'évolution de l'iqțāc du IXe au XIIle siècle: contribution à une histoire comparée des sociétés médiévales”, Annales, Économie, Sociétés, Civilisation 1: 25-52. 
Cahen, Claude (1956), “Notes pour l'histoire de la ḥimāya”, Mélanges Louis Massignon, 3 vols., Damascus: Institut Français de Damas, I, 287-303.

Campopiano, Michele (2011), “Land Tax 'alā l-misāḥa and muqāsama: Legal Theory and the Balance of Social Forces in Early Medieval Iraq $\left(6^{\text {th }}-8^{\text {th }}\right.$ Centuries C.E.)", Journal of the Economic and Social History of the Orient 54: 239-269.

Crone, Patricia (1980), Slaves on Horses. The Evolution of the Islamic Polity, Cambridge: Cambridge University Press.

Décobert, Christian (1981), Le mendiant et le combattant: l'institution de l'Islam, Paris: Seuil. Elad, Amikam (1992), "Two Identical Inscriptions from Jund Filastîn from the Reign of the 'Abbāsid Caliph, Al-Muqtadir", Journal of the Economic and Social History of the Orient 35: 301-360.

Elad, Amikam (2016), The Rebellion of Muhammad al-Nafs al-Zakiyya in 145/762: Taalibīs and Early 'Abbāsids in Conflict, Leiden/Boston: Brill.

Fiey, Jean-Maurice (1968), Assyrie chrétienne III, Beirut: Imprimerie Catholique.

Fiey, Jean-Maurice (1980), Chrétiens syriaques sous les Abbassides surtout à Bagdad (749-1258), Louvain: CSCO.

Fiey, Jean-Maurice (1990), “Les Nabaț de Kaškar-Wasit dans les premiers siècles de l'Islam”, Mélanges de l'Université Saint-Joseph 51: 49-87.

Gil, Moshe (2004), Jews in Islamic Countries in the Middle Ages, Leiden/Boston: Brill.

Goode, Alexander (1940), “The Exilarchate in the Eastern Caliphate, 637-1258”, The Jewish Quarterly Review 31: 149-169.

Kennedy, Hugh (2004), “Elite Incomes in the Early Islamic State”, in: John F. Haldon and Lawrence Conrad, eds., Elites Old and New in the Byzantine and Early Islamic Near East, Princeton: Darwin Press, 13-28.

Kennedy, Hugh (2014), “Landholding and Law in the Early Islamic State”, in: John Hudson and Ana Rodríguez, eds., Diverging Paths? The Shapes of Power and Institutions in Medieval Christendom and Islam, Leiden/Boston: Brill, 159-181.

Lokkegaard, Fred (1950), Islamic Taxation in the Classical Period, with Special References to Circumstances in Iraq, Copenhagen: Branner and Korch.

Morony, Michael (1981), “Landholding in Seventh-Century Iraq: Late Sasanian and Early Islamic Patterns”, in: A. L. Udovitch, ed., The Islamic Middle East, 700-900: Studies in Economic and Social History, Princeton: Darwin Press, 135-175.

Morony, Michael (1984a), Iraq after the Muslim Conquest, Princeton: Princeton University Press.

Morony, Michael (1984b), "Landholding and Social Change: Lower al-Irāq in the Early Islamic Period”, in: Tarif Khalidi, ed., Land Tenure and Social Transformation in the Middle East, Beirut: American University of Beirut, 209-222.

Newman, Rabbi J. (1932), The Agricultural Life of the Jews in Babylonia, London: Oxford University Press.

Noth, Albrecht (1973), "Zum Verhältnis von kalifaler Zentralgewalt und Provinzen in umayyadischer Zeit. Die 'Șulḥ’-“Anwa'- Traditionen für Ägypten und den Iraq”, Die Welt des Islam 14: 150-162; (2008), "On the Relationship in the Caliphate between Central Power and the Provinces: The 'Șulh'-“Anwa' Traditions for Egypt and Iraq”, in: Fred M. Donner, ed., The Expansion of the Early Islamic State, Aldershot: Ashgate/Variorum. 
Noth, Albrecht (1984), "Some Remarks on the Nationalization of Conquered Lands at the Time of the Umayyads", in: Tarif Khalidi, ed., Land Tenure and Social Transformation in the Middle East, Beirut: American University of Beirut, 223-228.

Payne, Richard (2015), “East Syrian Bishops, Elite Households, and Iranian Law after the Muslim Conquest”, Iranian Studies 48/1: 5-32.

Putman, Hans (1975), L'Église et l'Islam sous Timothée I (780-823). Une étude sur l'église nestorienne au temps des premiers 'Abbassides, Beirut: Dar el Mashreq éditeurs.

al-Qāḍī, Wadād (2006), "Population Census and Land Surveys under the Umayyads (41-132/661-750)”, Der Islam 83: 341- 416.

al-Qāọī, Wadād (2010), "The Names of Estates in State Registers Before and After the Arabization of the 'dīwāns'”, in: John Hudson and Ana Rodríguez, eds., Diverging Paths? The Shapes of Power and Institutions in Medieval Christendom and Islam, Leiden/Boston: Brill, 255-280.

Robinson, Chase F. (2000), Empire and Elites after the Muslim Conquest: The Transformation of Northern Mesopotamia, Cambridge: Cambridge University Press.

al-Sāmarrāie, Ḥusām Qawām (1972), Agriculture in Iraq During the $3^{\text {rd }}$ Century, Beirut: Librairie du Liban.

Sourdel, Dominique (1960), Le vizirat 'abbāside de 749 à 936 (132 à 324 de l'hégire), 2 vols., Damascus: IFPO.

Tillier, Mathieu (2009), Les cadis d'Iraq et l'etat Abbasside (132/750-334/945), Damascus: IFPO.

Tillier, Mathieu (2006), “Un traité politique du iie/viiie siècle. L'épître de 'Ubayd Allāh b. al-Ḥasan al-'Anbarī au calife al-Mahdī”, Annales islamologiques 40: 139-170.

Verkinderen, Peter (2018), “Land Reclamation and Irrigation Programs in Early Islamic Southern Mesopotamia: Self-Enrichment vs State Control”, in: Marie Legendre, Alain Delattre, and Petra Sijpesteijn, eds., Authority and Control in the Countryside. From Antiquity to Islam in the Mediterranean and Near East (6th-10th Century), Leiden: Brill, 500-527. 